\title{
The financial fragility hypothesis and the debt crisis in Italy in the 2010s
}

\author{
Ivan Rozmainsky \\ National Research University Higher School of Economics, Saint Petersburg, Russia, e-mail: irozmain@yandex.ru \\ Tatyana Rodionova \\ National Research University Higher School of Economics, Saint Petersburg, Russia, e-mail: trodionova@hse.ru
}

Citation: Rozmainsky, I., Rodionova, T. (2021). The financial fragility hypothesis and the debt crisis in Italy in the 2010s. Terra Economicus 19(1): 6-16. DOI: 10.18522/2073-6606-2021-19-1-6-16

The paper attempts to analyze the characteristics of current debt crisis in Italy based on the financial fragility hypothesis developed by Hyman Philip Minsky. Our main suggestion is that in the private sector of the Italian economy after the 2011 crisis fragile types of financing prevailed over hedge types. We test it using the 2013-2017 data for 163 Italian private non-financial companies. Based on the data obtained, authors constructed indices according to three methodologies that distinguish firms as hedge, speculative and Ponzi, in order to determine the degree of financial fragility of the private sector of the Italian economy. The results showed that the economy of Italy in 2013-2017 remains financially fragile, despite the increase in the share of hedge companies. This outcome implies that austerity measures are not good "remedy" for this economy. Such policies diminish economic activity, in general, and flow of business profits, in particular. It creates difficulties to escape from fragile financial position.

Keywords: financial fragility hypothesis; Minsky; financial instability hypothesis; debt crisis; Italy

JEL codes: E12, E32, E44, E52

\section{Гипотеза финансовой хрупкости и долговой кризис в Италии 2010-х годов}

\author{
Иван Вадимович Розмаинский \\ Национальный исследовательский университет - Высшая школа экономики \\ г. Санкт-Петербург, Россия, e-mail: irozmain@yandex.ru \\ Татьяна Игоревна Родионова \\ Национальный исследовательский университет - Высшая школа экономики \\ г. Санкт-Петербург, Россия, e-mail: trodionova@hse.ru
}

Цитирование: Rozmainsky, I., Rodionova, T. (2021). The financial fragility hypothesis and the debt crisis in Italy in the 2010s. Terra Economicus 19(1): 6-16. D0I: 10.18522/2073-6606-2021-19-1-6-16

В статье делается попытка проанализировать характеристики текущего долгового кризиса в Италии на основе гипотезы финансовой хрупкости, разработанной Хайманом Филипом Мински. Наша главная гипотеза состоит в том, что в частном секторе итальянской экономики после кризиса 2011 года хрупкие

(С И.В. Розмаинский, Т.И. Родионова, 2021 
режимы финансирования преобладали над хеджевым режимом. Мы тестируем эту гипотезу на данных за 2013-2017 годы по 163 итальянским частным нефинансовым компаниям. На основе полученных данных авторы построили индексы согласно трем методологиям, на основе которых осуществляется классификация фирм на хеджевые, спекулятивные и Ропzі. Это было сделано, чтобы определить степень финансовой хрупкости частного сектора итальянской экономики. Результаты показали, что экономика Италии в 2013-2017 годах оставалась финансово хрупкой, несмотря на увеличение доли хеджевых компаний, то есть компаний, практиковавших хеджевый режим финансирования. Такой результат означает, что политика строгой экономии не является хорошим «лекарством» от «болезней» итальянской экономики. Такая политика снижает экономическую активность в целом и поток прибылей бизнеса в частности. Это создает трудности для выхода из состояния финансовой хрупкости.

Ключевые слова: гипотеза финансовой хрупкости; Мински; гипотеза финансовой нестабильности; долговой кризис; Италия

\section{Introduction}

As is known, recently the Great Recession - the largest global economic crisis after the Great Depression - took place. In Europe, the Great Recession manifested itself in the form of the debt crisis of 2009-2011, which first gripped Greece and Ireland, and then spread to most of the EU countries. Italy was no exception. In this country, the crisis began in the second half of 2011, the cause of which was the collapse of the government bond market in Greece at the end of 2009. The reaction to the process of growth of public debt (in 2011 its value reached $120 \%$ of GDP), combined with a slow economic growth rate was the lowering of the sovereign credit rating from A + to A by the S\&P agency, which rated Italy's government bonds as securities with increased risk. Thus, the country stood on the same level with Malta, behind Estonia and Slovenia and ahead of only Cyprus, Ireland, Portugal and Greece. However, Italy is a larger country in scale, significance and impact. Compared with Greece, whose economy at that time was $2.7 \%$ of EU GDP, Italy's debt accounted for one third of the total debt in the Eurozone. Therefore, it is not surprising that since 2011 the main problem of the political and economic elites of the European Union has been the "contamination" of the Italian economy. At the same time, the significance of the crisis is great not only in terms of a short-term perspective, but also in terms of its duration and the recovery of the Italian economy (Bull, 2018: 14; Cencig, 2012: 12).

In connection with a broad discussion of crisis phenomena over the past ten years, as well as dissatisfaction with orthodox theories, there is a proposal to turn to heterodox currents. One of such theories, alternative to the theory of the mainstream, is the financial fragility hypothesis (it is also known as the financial instability hypothesis), created by the American economist Hyman Philip Minsky (1919-1996) in the late 1970s - early 1980s. This theory shows that periods of stability can change the financial behavior and institutional environment in a way that contributes to increased financial fragility, the shoots of which can grow into a financial collapse. Thus, the financial fragility hypothesis (hereinafter referred to as the FFH) can be a convenient tool for analyzing the causes and consequences of financial crisis phenomena (Nikolaidi, 2017: 222).

The purpose of this work is to analyze the debt crisis in Italy using the FFH. The hypothesis of the study can be formulated as follows: in the private sector of the Italian economy after the 2011 crisis, fragile types of financing prevailed over hedge types. Such dominance is a logical continuation of debt deflation, in which agents prefer debt reduction.

Firstly, we discuss the basic concepts on which Minsky's theory is based. Then we will review the main empirical studies on the public and private sectors of the economies of various countries. After that, we will describe the data used for the analysis, as well as the main methodologies that were used to calculate the financial fragility of companies. In the conclusion, the main results obtained during the study will be summarized. 


\section{Minsky's theory as the correct interpretation of Keynes's legacy}

The FFH was developed by Minsky as an attempt to implement the correct interpretation of the theory of John Maynard Keynes. Referring to this theory, Minsky showed that contemporary market economies can be explained with the help of the "capitalist economic process", in which such concepts as uncertainty, cyclicality (of this process) and financial relations of a capitalist economy are of no small importance. These provisions were ignored by Hicks, Samuelson and other worldrenowned economists, who created the generally accepted version of Keynesianism in their works. Uncertainty is treated as a phenomenon that cannot be reduced to risk. In case of uncertainty, we are not aware of either the number of future possible outcomes or the probability of each of them. As Keynes (1937: 213-214) wrote, “... by "uncertain" knowledge, let me explain, I do not mean merely to distinguish what is known for certain from what is only probable. The game of roulette is not subject, in this sense, of uncertainty; ... the expectation of life is only slightly uncertain. ... The sense in which I am using is that in which the prospect of European war is uncertain, or the price of copper and the rate of interest twenty years hence, or the obsolescence of a new invention, or the position of private wealth-owners in the social system of 1970. About these matters there is no scientific basis on which to form any calculable probabilities whatever. We simply do not know". From Minsky's point of view, uncertainty covers both investment and financial decisions of economic units. Both the determination of the volume of investments in fixed assets and the choice of methods for its financing occur under conditions of uncertainty (Minsky, 1977: 5; 1975: 67; 1986).

Hence, there is the connection between uncertainty, the cyclical nature of the capitalist economy and its financial sphere To protect against uncertainty, highly liquid assets are used, primarily money; an increase in demand for such assets, combined with a fall in demand for fixed capital and other productive assets, can lead to an economic downturn. On the contrary, a decrease in the demand for money - coupled with an increase in the volume of productive investment - can lead to an economic expansion (Arestis, 1988: 42). This is the reason for the cyclical nature of economic dynamics, which is aggravated by the processes that will be discussed further.

In connection with the analysis of the financing of investments, Minsky developed the concept of endogenous money supply proposed by Keynes in some of his works (Keynes, 1939). The British economist tried to show the endogenous nature of creating money supply: to buy capital, an entrepreneur must first take money from a financial institution, which, in turn, issuing loans to business investors, generates new money supply. As a result, the process of creating money acquires endogenous features. From Minsky's point of view, money is an asset that is created endogenously for the acquisition of capital (Minsky, 1977: 7; 1986). However, if the financial institution does not have enough money to issue a loan, it can satisfy the entrepreneur's demand for money by resorting to innovative financial schemes. So, Fernandez, Kaboub and Todorova considered the causes of the mortgage crisis in the United States in 2007 and concluded that financial innovations matter, namely, securitization, mortgage loans with a regulated interest rate, etc. All this only leads to an economic destabilization, endogenously increasing the money supply (Fernandez et al., 2008: 5). Such a course of events was predicted by Minsky long before its actual implementation. What is important here is the fact that external financing of investments and other expenses can be a powerful factor in destabilizing the economy. In the phase of expansion, by accumulating debts, firms expand the possibilities of financing their expenditures, but by the time a recession sets in, these debts seem to be "pulling" them into bankruptcy. As a result, the actual onset of recession is caused by the accumulation of debts due to external financing of investments.

\section{How and why does the crisis come, according to the FFH?}

According to the FFH, economic dynamics is concerned with the fact how firms finance their fixed capital investments. At the beginning of the upward stage of the business cycle (in the phase of expansion) hedge finance prevails, in which the current cash inflows of firms are sufficient to pay off the debt, including interest on it. This regime of financing is largely a consequence of the greater reliance of firms on domestic financial sources than on external funds. This is explained by the fact 
that in the phase of expansion in the memory of economic units the memories of the recent depression are still fresh.

However, these memories gradually fade away, in particular, because the national income generated by investments in the conditions of the hedge finance regime increases. As a result, firms are actively switching to external financing of capital investments. After a while, a situation occurs in which the cash receipts of many firms are sufficient only to pay interest on debts, but they are not enough to pay off the principal. In order not to become bankrupt, such firms are forced to take new loans in order to pay off old ones. This regime of financing was named by Minsky as speculative finance. In the case of rising interest rates or falling cash receipts of firms, speculative finance inevitably transforms into Ponzi finance, where these revenues are not enough even for regular interest payments. In such a situation, the only way out is to increase the amount of debt to pay off old loans. If speculative finance is characteristic of the boom phase, then Ponzi finance leads to the transition of the economy from this phase to the recession phase. This is due to the fact that, sooner or later, firms applying the last described regime of financing will not be able to get new loans either because of the unwillingness of lenders to continue issuing loans, or because of a general lack of financial resources in the economy (Beshenov, Rozmainsky: 2015).

Thus, the most important cause of periodic debt crises is the systematic inability of the sector of firms to repay their debts to the financial sector. This is one of the main findings of the FFH. Another main conclusion is that during the business cycle, the financial system becomes more and more fragile, i.e. there is a decrease in the liquidity of the balance sheets of economic entities. To restore the stability of economic units, it is necessary to restructure debt, reduce costs and contractual obligations and increase the maturity of debt. Such steps will help Ponzi units to become speculative ones, and speculative units to become hedge ones (Vercelli, 2009: 7).

The idea is that the economy becomes more instability-prone as it accumulates financial fragility was proposed, in particular, in the famous paper by Lima and Meirelles (2007). It is one of the most successful attempts to model formally the FFH. One of the main conclusions is that a long-run equilibrium in the conditions of Ponzi regime will be unstable irrespective of the level of important macroeconomic variables (unlike a long-run equilibrium under hedge regime).

In this vein the paper by Charles (2008) also deserves attention. It proposes a simple Post Keynesian model of capital accumulation; but this process is directly linked to the state of the financial structure. This structure evolves from robust position to fragile one as economic expansion develops. This model shows essential Minskyan outcome: stability is destabilizing, and financial instability is not a "special case", but a systemic feature (Charles, 2008: 329).

These ideas were developed in the seminal paper by Nishi (2012). This author has constructed model linking between mechanisms of debt-led and debt-burdened growth regimes and Minskyan financial structure. The main result is that debt-led growth is at most conditionally stable, debtburdened growth is at least conditionally stable (Nishi, 2012: 657).

All these papers laid the foundation for empirical application of the FFH discussed below. We would like to note that the very detailed review of recent formal Minskyan models can be found in paper by Nikolaidi and Stockhammer (2017).

These ideas of "destabilizing stability" and "accumulation of financial fragility" turned out to be popular when analyzing the financial and economic crises of the past decades. Next, we will discuss how the FFH was applied in the study of such crises.

\section{Empirical Analysis of the Public Sector on the Base of the FFH}

One of the first empirical applications of the FFH to the problems of developing countries was the work of Schroeder, devoted to the economy of Thailand from 1984 to 1999. This country turned out to be the most representative example for the study of the financing regimes of Minsky during the Asian crisis of 1997. In the course of this study, the author concludes that the attraction of foreign funds played an important role in worsening the financial situation of Thailand. Also, based on a mathematical model, Schroeder explains why the country was in crisis: "Crisis, in 1997, is character- 
ized by sudden increase in the interest rate, a negative rate of profit and continuing rate of return on stock market, a dramatic slowing of capital accumulation, and improving current account (which was enhanced later by the devaluation of the baht)" (Schroeder, 2002: 22). Thus, the author confirmed that at the level of the public sector, the country entered the Ponzi regime in 1997.

Another study that deserves attention is the work of Ferrari-Filho, Terra and Conceição (FerrariFilho et al., 2010), which examines the public sector of the Brazilian economy from 2000 to 2007. To begin with, they point out that, despite the fact that in his work Minsky relies on the financial behavior of firms, the theoretical basis of his research can be used to analyze the problems of the public sector. Generally speaking, the authors are the first to apply the Minskyan taxonomy to the government sector, therefore, this paper is very important. To differentiate hedge, speculative and Ponzi financial positions, the authors created an index of financial fragility, which we use below. Based on it, they analyzed the debt crisis in Brazil with the help of the FFH. So, in the early 2000s, the financial structure in Brazil was speculative. As a result, public debt increased during this period, and the public sector could not conduct a "counter-cyclical fiscal policy". In other words, there were "diminishing degrees of freedom" for the possibilities of macroeconomic stabilization. By way of response, the Brazilian economy by 2007 approached a financial position like Ponzi. The authors predicted, to some extent, future macroeconomic difficulties of both the Brazilian economy and its public sector. In particular, they declared the necessity to reduce Brazil's basic interest rate and to eliminate the public debt indexation process (Ferrari-Filho et al., 2010: 164).

In 2009, Schroeder presented yet another empirical work, but already on the study of the crisis in New Zealand in the mid-2000s. As the author herself says, to create a mechanism for separating hedge, speculative, and Ponzi financial positions, she turned to a simple Minsky style cash flow analysis system. According to the results, New Zealand from 2005 to 2007 was in a state of financial fragility (Schroeder, 2009: 296).

G. Argitis and M. Nikolaidi presented in 2014 the study "The financial fragility and crisis of the Greek government sector". As in the aforementioned papers, the authors' goal was to develop financial instability indices for the public sector. Among the tasks was the study of the financial structure of the public sector of the Greek economy before and after the crisis in 2009. As a result, the authors, using the liquidity index, ascertained that in the early 2010 the financial vulnerability of the Greek public sector increased. The authors also stressed that austerity policies did not improve the financial situation in Greece (Argitis, Nikolaidi, 2014: 277).

These were some of the main empirical studies analyzing the classifications of hedge, speculative and Ponzi financial structures in the public sector.

\section{Empirical Analysis of the Private Sector on the Base of the FFH}

However, initially the FFH was developed to study the problems associated with financing the expenditures of the private sector. Therefore, we will further consider the main works, analyzing the indicators making possible to evaluate the regimes of financing to determine the fragility of the financial systems.

One of the early empirical works devoted to this problem is a paper by Tymoigne (2010). This author proposed a sectoral analysis of Ponzi-financing households in the United States from 1987 to 2009. A central aspect of Ponzi-financing, according to the author, is that net cash flows are very low and do not finance completely principal and interest repayments (Tymoigne, 2010). Therefore, he suggests that three ratios should be considered together: cash flow, liquidity and the need for refinancing. The combination of increased cash flow ratios and refinancing needs together with a decrease in liquidity ratios is an indicator of Ponzi-financing. Based on the indicator compiled by him, the author concludes that from 2000 to 2007 US households were prone to Ponzi-financing (Tymoigne, 2010: 34).

Another noteworthy work (Mulligan et al., 2014) analyzes quarterly data from 2002 to 2009 of 8707 North American companies. These data are classified according to the regime of financing according to a criterion such as the interest coverage ratio (discussed in detail below). The results 
showed that throughout the relevant period, the share of Ponzi and speculative types of financing firms was about $62-73 \%$. It indicates the fragile state of the economy at that time and is consistent with the results of the aforementioned study of Tymoigne (2010).

The authors of newest study on the private sector of the US economy - Davis et al. (2017) - applied the FFH to non-financial companies in this country. Data were taken from 1970 to 2014. What is surprising is that since the late 1970s most of the firms adhered to the speculative type of financing, although the number of Ponzi units rapidly increased from $10.8 \%$ in 1970 to $31.6 \%$ in 2014 . Furthermore, the authors note that many firms adhering to the Ponzi-financing system are becoming public in recent years. This means that a long wave of growing fragility is a response to changes in financial norms and conventions, as evidenced by the 2008 financial crisis (Davis et al., 2017).

Among the works on the financial fragility of European countries, it should be mentioned the paper by Beshenov and Rozmainsky (2015). In this work the FFH is used to analyze both the public and private sectors of the Greek economy. The investigation of the private sector is especially important. The authors analyzed the financial activities of 36 Greek companies from 2001 to 2014. The Minskyan taxonomy of financial fragility was constructed with use of ratio of EBIT to interest expenses. Based on the data, the following result was obtained: "Between 2001 and 2008, the number of companies with speculative and Ponzi financing increased" (Beshenov, Rozmainsky, 2015: 17). By the end of 2013, the share of companies with a sustainable type of financing was only $17 \%$ of the total sample size. Like Argitis and Nikolaidi (2014), the authors point to the inconsistency of austerity policies in today's realities.

The financial fragility of non-financial private companies in Japan was investigated by Nishi (2016). He uses data at the firm level to classify Japanese enterprises by type of financing, according to the FFH, and then analyzes financial fragility indicators using logit regression. In the model, he uses annual data for the period from 1975 to 2014, and his database includes firms from 32 different sectors, which were divided into two groups: production and non-production, and then into small, medium and large enterprises. Two indicators of financial fragility were constructed. The first financial fragility index is built on the basis of the cash flow accounting structure used by Schroeder (Schroeder, 2009), but applied to firms, not to the entire economy. The second index is based on "three margins of safety". An innovation in the study is the accounting of dividend payments (but this innovation, to our mind, can be disputable, as we will discuss below). The main conclusion of the study is that the non-production sector in Japan was more financially fragile than the production sector during the relevant period (Nishi, 2016).

Torres Filho et al. (2017) and Caldentey et al. (2018) are one of the most recent available empirical studies. These works, in fact, summarize all previous publications. The first of these studies devotes to the debt crisis in Brazil from 2007 to 2015 and is based on the methodology that was proposed in the work (Davis et al., 2017). The authors refined this methodology and developed their own index of financial fragility. The second work is a study of corporate debt in Latin America for 2009-2016 based on methodologies developed in the publications of Mulligan et al. (2014) and Torres Filho et al. (2017). However, besides calculating indicators for 2241 firms, the authors of this work (Caldentey et al., 2018) also constructed an econometric model with robust errors. In this model, the investment of the company acts as a dependent variable, and a number of indicators are independent. These indicators include: the cash flow of the previous period, the ratio of total debt to total liabilities, the cash flow in the previous period is below the cut-off level, the cash flow in the previous period is above the cutoff level, the international real interest rate in the previous period, the ratio of current assets to total assets in the previous period, the ratio of current liabilities to total liabilities in the previous period. Significant in the model at $1 \%$ and $5 \%$ significance level were the international real interest rate in the previous period and the ratio of current liabilities to total liabilities in the previous period, respectively. However, these variables also turned out to have a negative effect on the firm's investments.

A more comprehensive analysis of sources and results can be found in (Novikova, Rozmainsky, 2020).

Based on the reviewed works, we decided to apply the FFH to the current state of the private sector of the Italian economy. We considered the data for 2013-2017 for 163 Italian companies, which were selected based on the following criteria: 
- affiliation of companies to the non-financial private sector; we have excluded firms belonging to the financial sector or owned by the state;

- unavailability of data on other companies for the relevant period;

- lack of participation of this company in the processes of mergers and acquisitions.

The annual financial statements of the companies under consideration were taken from such analytical platforms as Thomson Reuters, Morningstar and The Wall Street Journal for the period in question.

Then we tried to "diagnose" whether these companies are financially fragile using the three methods presented in the papers just reviewed.

\section{Analysis of the debt crisis of the private sector in Italy: Mulligan's methodology}

In some of the above papers, criteria and thresholds were given for the distinction between the regimes described by Minsky. One of these works is Mulligan (2013). As a criterion, the authors used the Interest Coverage Ratio, which can be defined as the ability of a company to cover its debts:

$$
\text { Interest Coverage Ratio }=\frac{(\text { Net Income }+ \text { Interest Expense })}{\text { Interest Expense }} .
$$

The authors classify firms by regimes as follows: the interest coverage ratio, greater than or equal to 4 units, is determined by hedge firms, from 4 to 0 - speculative, less than 0 - Ponzi.

Based on this indicator, we calculated the ratio of companies defined as hedge, speculative and Ponzi, according to the FFH. Descriptive statistics has been presented in Table 1. During the relevant period, there is a prevalence of firms with speculative and Ponzi types of financing, which indicates an unfavorable state of the private sector of the economy.

The number of companies by regimes: Mulligan's methodology

Table 1

\begin{tabular}{|l|c|c|c|c|c|}
\hline & $\mathbf{2 0 1 3}$ & $\mathbf{2 0 1 4}$ & $\mathbf{2 0 1 5}$ & $\mathbf{2 0 1 6}$ & $\mathbf{2 0 1 7}$ \\
\hline HEDGE & 49 & 61 & 64 & 71 & 77 \\
\hline SPECULATIVE & 78 & 71 & 63 & 66 & 50 \\
\hline PONZI & 34 & 29 & 35 & 24 & 33 \\
\hline NO DATA & 2 & 2 & 1 & 2 & 3 \\
\hline
\end{tabular}

The percentage of Ponzi-firms for 2013-2017 was relatively stable, with the exception of 2016, when this indicator dropped to $14 \%$. The number of firms with a speculative type of financing was reduced (from 47\% to 31\% relative to the total number of firms) from 2013 to 2017 . The change in the number of firms with hedge type of financing, on the contrary, had a positive trend in the same period (from $30 \%$ to $47 \%$ ). This means that an increasing number of firms began to rely not on external sources of financing, but on internal ones. Thus, an increasing number of firms began to realize too high risks for themselves and began to return their debts to lenders. Nevertheless, the ratio of speculative and Ponzi-firms to hedge units at the end of 2017 suggests that the Italian economy is still fragile enough to talk about its possible recovery, despite positive tendencies.

\section{Analysis of the debt crisis of the private sector in Italy: Nishi's methodology}

Along with the methodology of Mulligan, a number of scientific articles also quite often mention the methodology of Nishi, which is based on Minsky's theory (Nishi, 2016). In his work, Nishi offers two indicators of financial fragility, based on cash flow accounting and on balance sheet accounting. However, due to lack of data, building an index on the basis of the balance sheet of firms seems impossible. 
To calculate the first index, Nishi uses the "sources and use of funds" approach. In other words, the sources of funds are the sum of profits and loans; the use is the sum of investment payments, debt service and dividends. Each of the proposed variables was normalized to the fixed capital, since the values between firms can vary greatly. Thus, the following ratios of normalized variables determine the regimes described by Minsky:

$$
\begin{aligned}
& \text { Hedge: } r-g-i_{D}-d \geq 0, \\
& \text { Speculative: }\left\{\begin{array}{c}
r-g-i_{D}-d<0 \\
r-i_{D}-d \geq 0
\end{array},\right. \\
& \text { Ponzi: }\left\{\begin{array}{c}
r-g-i_{D}-d<0 \\
r-i_{D}-d<0
\end{array}\right.
\end{aligned}
$$

where $r$ - operating profits divided by fixed assets, $g$-investment divided by fixed assets, $i_{D}$-interest expenses divided by fixed assets, $d$ - dividends divided by fixed assets. Since for dividends there is no separate balance account in the company's financial statements, we calculated this indicator as follows:

$$
d_{t}=\text { retained earning } s_{t-1}+\text { net } \text { income }_{t}-\text { retained earnings } s_{t},
$$

where retained earnings $s_{t-1}$ - retained earnings in the previous period, retained earning $s_{t}$ - retained earnings in the relevant (current) period, net income t $_{t}$ net income in the relevant period.

After analyzing the financial statements of 163 companies, we were able to distribute them in accordance with the FFH classification. Descriptive statistics has been presented in Table 2.

The number of companies by regimes: Nishi's methodology

Table 2

\begin{tabular}{|l|c|c|c|c|}
\hline & $\mathbf{2 0 1 4}$ & $\mathbf{2 0 1 5}$ & $\mathbf{2 0 1 6}$ & $\mathbf{2 0 1 7}$ \\
\hline HEDGE & 82 & 80 & 61 & 84 \\
\hline SPECULATIVE & 9 & 10 & 14 & 21 \\
\hline PONZI & 72 & 73 & 88 & 58 \\
\hline
\end{tabular}

For 2014-2017 there was no big change in the ratio of companies with different regimes of financing (50\% hedge, $5 \%$ speculative, $44 \%$ Ponzi). The only exception is 2016 . This year was characterized by an increase in companies with a Ponzi-type of financing (54\%) and a decrease in firms with hedgetype financing (37\%). But in 2017, the ratio changed in the opposite direction $-52 \%$ hedge, $13 \%$ speculative, $35 \%$ Ponzi firms.

Comparing with the previous results, in general it can be noted that over the years of consideration both methodologies show the prevalence of the number of companies with fragile types of financing over the hedge one. Nevertheless, according to the results obtained, it can also be concluded that the financial fragility index invented by Nishi is more sensitive (by construction) to the Ponzi-type of financing than Mulligan's methodology.

\section{Analysis of the debt crisis of the private sector in Italy: Torres Filho at al.'s methodology}

Another methodology, which is of direct interest to us, was proposed in the work (Torres Filho et al., 2017). In the same way as Nishi, the authors start from accounting for the company's cash flow, namely, the main indicators of the receipt and use of funds are current financial inflows and current financial outflows. According to the authors, their ratio allows us to determine the types of financing used by companies. However, in practice, it is more difficult to determine the inflows and outflows of cash than in theory. Therefore, the authors also gave an empirical application to their ideas. As a result, Torres Filho et al. suggested Financial Fragility Index: 


$$
F F I_{i t}=\frac{\left(F O_{i t}+S T D_{i t}\right)}{E B I T D A_{i t}},
$$

where $F O_{i t}$ - financial liabilities (current liabilities), $S T D_{i t}$ - short-term liabilities, EBITDA $i t$ - profit before interest, taxes, depreciation.

The authors have outlined the following thresholds for the classification of firms by the regime: a firm is classified as hedge if the value of the financial fragility index is less than or equal to one. If the index of financial fragility is greater than one, then there are two options for classification: speculative, if the value of current liabilities is less than the value of profit before interest, taxes, depreciation; Ponzi, if, as in the speculative version, the value of current liabilities is less than the value of profit before interest, taxes, depreciation, and the value of short-term liabilities is greater than the value of profit before interest, taxes, depreciation. Also, companies with a negative profit before interest, taxes, depreciation are treated as Ponzi, despite the behavior of other variables. More formally, these conditions look like this:

$$
\begin{aligned}
& \text { Hedge: } F F I \leq 1, \\
& \text { Speculative: }\left\{\begin{array}{c}
F F I>1 \\
F O<E B I T D A
\end{array}\right. \\
& \text { Ponzi: }\left\{\begin{array}{c}
F F I>1 \\
F O<E B I T D A \\
S T D>E B I T D A
\end{array} \text { or } E B I T D A<0 .\right.
\end{aligned}
$$

After analyzing the accounting statements of 163 companies, we obtained the ratio of companies by type of financing according to the FFH. Descriptive statistics has been presented in Table 3.

\section{The number of companies by regimes: Torres Filho et al.'s methodology}

Table 3

\begin{tabular}{|l|c|c|c|c|c|}
\hline & $\mathbf{2 0 1 3}$ & $\mathbf{2 0 1 4}$ & $\mathbf{2 0 1 5}$ & $\mathbf{2 0 1 6}$ & $\mathbf{2 0 1 7}$ \\
\hline HEDGE & 59 & 62 & 66 & 69 & 77 \\
\hline SPECULATIVE & 80 & 73 & 76 & 77 & 67 \\
\hline PONZI & 22 & 27 & 21 & 17 & 19 \\
\hline NO DATA & 2 & 1 & 0 & 0 & 0 \\
\hline
\end{tabular}

From 2013 to 2017 the number of firms with hedge-type financing increased from $36 \%$ to $47 \%$ of the total number of companies under consideration. On the contrary, the number of firms with fragile types of financing decreased throughout the entire period: speculative decreased by from $49 \%$ in 2013 to $41 \%$ in 2017, Ponzi - from 13\% in 2013 to $11 \%$ in 2017. Despite the positive dynamics and the increase in the number of firms with hedge type of financing, a comparison of the ratios of fragile firms (53\%) and hedge ones (47\%) in 2017 leads to the conclusion that the private sector of the Italian economy is still quite unstable. It is possible that the regulatory measures applied by the government are ineffective.

If we compare the results obtained according to the methodology of Torres Filho et al., Nishi and Mulligan, then we can make an unequivocal conclusion about the fragility of the non-financial sector of the Italian economy in the period after the 2011 crisis, which confirms our hypothesis. Moreover, the results obtained using the indices proposed by Mulligan and Torres Filho et al., confirm the fact of debt deflation (hedge firms are growing when firms with fragile types of financing prevail). Due to above-mentioned considerations, we believe that both these methodologies are preferable than Nishi's methodology. Mulligan's methodology is more appropriate because it is explicitly concerned with interest expenses unlike the methodology of Torres Filho et al. 


\section{Conclusion}

According to the FFH, periods of stability are followed by periods of crisis due to changes in the financial behavior of economic units. Hence, the author of this conception - Minsky - and his supporters came to the idea of classifying economic units into categories depending on the degree of financial risk to which their balance sheets are exposed. These units can be classified as hedge, speculative, and Ponzi ones.

Despite the popularity of the considered conception, there are not so many empirical works at the moment. Therefore, our research can be a great contribution to the development of empirical applications of the FFH. The paper analyzed the dynamics of financial fragility in the private nonfinancial sector of the Italian economy from 2013 to 2017. For this, we collected data from the financial statements of 163 Italian companies. Based on the data obtained, we constructed indices according to three methodologies that distinguish firms as hedge, speculative and Ponzi, in order to determine the degree of financial fragility of the private sector of the Italian economy.

The results showed that the economy of Italy in 2013-2017 remained fragile, despite the increase in the share of hedge companies. Thus, this period can be described using the FFH. In addition, the results obtained using the methodologies proposed by Mulligan and Torres Filho et al., confirm the fact of debt deflation. We draw such a conclusion, since it is noticeable that a greater number of firms began to rely on internal sources of financing, and not on external ones. In other words, firms began to realize the riskiness of their type of financing and began to return their debts to financial institutions.

This outcome - that the Italian economy is financially fragile - implies that austerity measures are not good "remedy" for this economy. Such policies diminish economic activity, in general, and flow of business profits, in particular. It creates difficulties to escape from fragile financial position. In other words, austerity measures can be barrier to a transformation of the fragile firms into the hedge ones (the Portuguese positive experience concerned with the refusal from austerity policies see in: Novikova, Rozmainsky, 2020). It is useful to remember that the Italian economy is characterized by one of the slowest growth rates in the eurozone. This problem cannot be solved by austerity measures, in general, and in the conditions of financial fragility, in particular. It is an essential policy recommendation by our paper.

Furthermore, despite the similarity in identifying the main phenomenon - the fragility of the private sector of the economy - the methodologies yielded different results on the ratios of hedge, speculative, and Ponzi firms. So, unlike R. Mulligan, Torres Filho et al., the methodology of Nishi was more sensitive to the detection of Ponzi-types of firms. Also, based on the methodology of Nishi, we cannot confirm the fact of debt deflation in Italy in the period 2014-2017. Moreover, the ratio of various types of financing from 2014 to 2017 did not change, except for 2016, and was about the same, which also does not allow us to conclude that the Italian economy is fragile during this period. Thus, our hypothesis is confirmed by the results of using only two of the three methodologies.

Summing up, we would like to note that the indicators of financial fragility do not allow to predict - effectively and accurately - such situations as the bankruptcies of firms. The role they play is more likely to signal relatively key "vulnerabilities" in the balance sheets of companies. This makes it possible to resort to measures that prevent a "chain" of bankruptcies of economic units.

For the further development of the study, it is possible to collect data for firms over a longer period of time for other EU countries for a critical comparison of the results or their possible aggregation to detect a general trend in the evolution of the fragility of the economies of the European Union countries with subsequent analysis of the causes of crisis.

\section{References}

Arestis, P. (1988). Post-Keynesian theory of money, credit and finance. In: P. Arestis (ed.) Post-Keynesian Monetary Economics: New Approaches to Financial Modelling. Aldershot: Edward Elgar: 41-71.

Argitis, G., Nikolaidi, M. (2014). The financial fragility and the crisis of the Greek government sector. International Review of Applied Economics 28(3): 274-292.

Beshenov, S.V., Rozmainsky, I.V. (2015). Hyman Minsky's financial instability hypothesis and the Greek debt crisis. Russian Journal of Economics 1(4): 419-438. 
Bull, M.J. (2018). In the eye of the storm: the Italian economy and the eurozone crisis. South European Society and Politics 23(1): 13-28.

Caldentey, E.P., Favreau-Negront, N., Méndez Lobos, L. (2018). Corporate debt in Latin America and its macroeconomic implications. Levy Economics Institute of Bard College, Working Paper no. 904.

Cencig, E. (2012). Italy's economy in the Euro zone crisis and Monti's reform agenda. Berlin: SWP Working Paper FG1, 2012/05.

Charles, S. (2008). A Post-Keynesian model of accumulation with a Minskyan financial structure. Review of Political Economy 20(3): 319-331.

Davis, L.E., De Souza, J.P.A., Hernandez, G. (2017). An empirical analysis of Minsky regimes in the US economy. University of Massachusetts, Economic Department Working Paper Series, 224, no. 2017-08.

Fernandez, L., Kaboub, F., Todorova, Z. (2008). On democratizing financial turmoil: a Minskyan analysis of the subprime crisis. Levy Economics Institute of Bard College, Working Paper, no. 548.

Ferrari-Filho, F., Terra, F.H.B., Conceição, 0.A.C. (2010). The financial fragility hypothesis applied to the public sector: An analysis for Brazil's economy from 2000 to 2008. Journal of Post Keynesian Economics 33(1): 151-168.

Keynes, J.M. (1937). The general theory of employment. Quarterly Journal of Economics 51(2): 209-223.

Keynes, J.M. (1939). The process of capital formation. Economic Journal 49(195): 569-574.

Lima, G.T., Meirelles, A.J.A. (2007). Macrodynamics of debt regimes, financial instability and growth. Cambridge Journal of Economics 31(4): 563-580.

Minsky, H.P. (1975). John Maynard Keynes. New York: Columbia University Press.

Minsky, H.P. (1977). The financial instability hypothesis: An interpretation of Keynes and an alternative to "standard" theory. Challenge 20(1): 20-27.

Minsky, H.P. (1986). Stabilizing an Unstable Economy. New Haven, CT: Yale University Press.

Mulligan, R.F. (2013). A sectoral analysis of financial instability hypothesis. The Quarterly Review of Economics and Finance 53(4): 450-459.

Mulligan, R.F., Lirely, R., Coffee, D. (2014). An empirical examination of Minsky's financial instability hypothesis. Journal des Économistes et des Études Humaines 20(1): 1-17.

Nikolaidi, M. (2017). Three decades of modelling Minsky: what we have learned and the way forward. European Journal of Economics and Economic Policies: Intervention 14(2): 222-237.

Nikolaidi, M., Stockhammer, E. (2017). Minsky models. A structured survey. Journal of Economic Surveys 31(5): 1304-1331.

Nishi, H. (2012). A dynamic analysis of debt-led and debt-burdened growth regimes with Minskyan financial structure. Metroeconomica 63(4): 634-660.

Nishi, H. (2016). An empirical contribution to Minsky's financial fragility: Evidence from non-financial sectors in Japan. Kyoto University, Graduate School of Economics Discussion Paper Series E-16-007.

Novikova, A.Yu., Rozmainsky, I.V. (2020). The non-financial private firms' sector of Portugal in 2001-2017: The financial fragility hypothesis-based analysis. Voprosy Ekonomiki (3): 115-128. [In Russian]

Schroeder, S.K. (2002). A Minskyan analysis of financial crisis in developing countries. Center for Economic Policy Analysis Working Paper, 9.

Schroeder, S.K. (2009). Defining and detecting financial fragility: New Zealand's experience. International Journal of Social Economics 36(3): 287-307.

Torres Filho, T.E.T., Martins, N., Miaguti, C.Y. (2017). Minsky's financial fragility: An empirical analysis of electricity distribution companies in Brazil (2007-15). Levy Economics Institute of Bard College, Working Paper, no. 896.

Tymoigne, É. (2010). Detecting Ponzi finance: An evolutionary approach to the measure of financial fragility. Levy Economics Institute of Bard College, Working Paper, no. 605.

Vercelli, A. (2009). A perspective on Minsky moments: the core of the financial instability hypothesis in light of the subprime crisis. Levy Economics Institute of Bard College, Working Paper, no. 579. 